\title{
Aerosol Distribution During Open Suctioning and Long-Term Surveillance of Air Quality in a Respiratory Care Center Within a Medical Center
}

\author{
Fen-Fang Chung PhD RN, Hui-Ling Lin MSc RRT RN FAARC, Hsueh-Erh Liu PhD RN, \\ Angela Shin-Yu Lien MSc RN, Hsiu-Feng Hsiao MSc, \\ Lan-Ti Chou MSc, and Gwo-Hwa Wan PhD
}

\begin{abstract}
BACKGROUND: The investigation of hospital air quality has been conducted in wards, ICUs, operating theaters, and public areas. Few studies have assessed air quality in respiratory care centers (RCCs), especially in mechanically ventilated patients with open suctioning. METHODS: The RCC air quality indices (temperature, relative humidity, levels of $\mathrm{CO}_{2}$, total volatile organic compounds, particulate matter [PM], bacteria, and fungi) were monitored over $1 \mathrm{y}$. The air around the patient's head was sampled during open suctioning to examine the probability of bioaerosol exposure affecting health-care workers. RESULTS: This investigation found that the levels of indoor air pollutants $\left(\mathrm{CO}_{2}, \mathrm{PM}\right.$, bacteria, and fungi) were below the indoor air quality standard set by the Taiwan Environmental Protection Agency. Meanwhile, the levels of total volatile organic compounds sometimes exceeded the indoor air quality standard, particularly in August. The identified bacterial genera included Micrococcus species, Corynebacterium species, and Staphylococcus species, and the predominant fungal genera included yeast, Aspergillus species, Scopulariopsis species, and Trichoderma species. Additionally, airborne $\mathbf{P M}_{2.5}, \mathbf{P M}_{1}$, and bacteria were clearly raised during open suctioning in mechanically ventilated patients. This phenomenon demonstrated that open suctioning may increase the bacterial exposure risk of health-care workers. CONCLUSIONS: RCC air quality deserves long-term monitoring and evaluation. Health-care workers must implement self-protection strategies during open suctioning to ensure their occupational health and safety in health-care settings. Key words: respiratory care center; indoor air quality; bioaerosol; open suctioning; mechanically ventilated patient; health-care workers. [Respir Care 2015;60(1):30-37. () 2015 Daedalus Enterprises]
\end{abstract}

\section{Introduction}

The main sources of indoor bioaerosols in the studied hospital are patients, families, and health-care workers. Contamination risks may be increased by a central air

\footnotetext{
Ms Chung is affiliated with the Department of Nursing, Chang Gung University of Science and Technology; Dr Liu and Ms Lien are affiliated with the School of Nursing, College of Medicine, Chang Gung University; Ms Lin, Ms Hsiao, and Dr Wan are affiliated with the Department of Respiratory Therapy, College of Medicine, Chang Gung University; Ms Hsiao and Ms Chou are affiliated with the Department of Respiratory Therapy, Chang Gung Memorial Hospital, Tao-Yuan, Taiwan, Republic of China.
}

Ms Chung and Ms Lin are co-first authors of this paper. conditioning system or by contact between health-care workers and patients. Critically ill patients in the ICU are frequently immunocompromised, and undergo numerous invasive procedures. Such patients thus suffer an increased

\footnotetext{
This study was supported by grant NSC101-2314-B-182-049 from the National Science Council of Taiwan. The authors have disclosed no conflicts of interest.

Correspondence: Gwo-Hwa Wan PhD, Department of Respiratory Therapy, College of Medicine, Chang Gung University, 259, Wen-Hwa 1st Road, Kwei-Shan, Tao-Yuan 333, Taiwan, Republic of China. E-mail: ghwan@mail.cgu.edu.tw.
}

DOI: $10.4187 /$ respcare. 03310 
risk of upper airway infections. ${ }^{1-4}$ Consequently, hospital air quality is enormously important.

Hospital air quality indices include temperature and humidity, ${ }^{5}$ levels of $\mathrm{CO}_{2}$, total volatile organic compounds (TVOCs), ${ }^{5}$ particulate matter (PM) ${ }^{6,7}$ bacteria, ${ }^{6,8,9}$ fungi, ${ }^{8}{ }^{810,11}$ viruses, ${ }^{12}$ and toxic metals. ${ }^{7}$ Both temperature and relative humidity were the recommended indices to reflect the efficiency of ventilation systems in hospitals. ${ }^{13}$ The most important index for evaluating indoor air quality was $\mathrm{CO}_{2}$ concentration, since it was correlated with both number of persons in a space and the PM concentrations, ${ }^{14,15}$ and was significantly related to airborne bacterial count. ${ }^{16}$ A previous study showed an association between PM concentrations and nearby human activity, exchange frequency, and filtration system effectiveness. ${ }^{17}$ Additionally, the TVOCs could release to the air from building structural materials, glues and rubbers in the air conditioning system, or chemical solvents.

The research on hospital air quality has primarily been conducted in wards and ICUs, ${ }^{10,18,19}$ operating theaters and postoperative recovery rooms, ${ }^{20-22}$ and public areas. ${ }^{7,23-28}$ Slezakova et al $^{7}$ found high averaged 24-h particulate matter $\left(\mathrm{PM}_{10}\right.$ and $\left.\mathrm{PM}_{2.5}\right)$ in a Portuguese hospital. Moreover, a previous study found that $90 \%$ of $\mathrm{CO}_{2}$ samples in the ICU of a medical center in northern Taiwan exceeded $1,000 \mathrm{ppm}$, and $20 \%$ of $\mathrm{PM}_{2}$ samples failed to meet the air quality standard set by the United States Environmental Protection Agency (EPA). Seasonal changes were observed in airborne bacterial and fungal concentrations in the ICU. ${ }^{19}$ Gram-positive bacteria (such as Bacillus species, Micrococcus species, and Staphylococcus species) were commonly found in the monitored operating rooms. ${ }^{22}$ The postoperative recovery room had considerably higher $\mathrm{CO}_{2}$ and bacterial concentrations than the operating theaters. ${ }^{21}$ Perdelli et $\mathrm{al}^{18}$ found that the use of an air conditioning system with a high efficiency particulate air filter markedly reduced airborne bacterial and fungal concentrations.

In the Taiwanese health-care system, patients receiving mechanical ventilation exceeding $21 \mathrm{~d}$ in the ICU must transfer to a respiratory care center (RCC) for weaning off assisted ventilation and further care. These patients are frequently diagnosed with upper airway infection owing to compromised immunity. In clinical practice, mechanically ventilated patients must be suctioned repeatedly using an endotracheal tube to remove secretions, maintain optimal oxygenation, reduce breathing effort, and prevent atelectasis and infection. Technically, suctioning systems can be divided into two types: open and closed. A previous study indicated higher bacterial concentration in the surrounding air and higher ventilator-associated pneumonia rate in patients following open suctioning compared with closed suctioning. ${ }^{29}$ Thus, the air quality of the RCCs warrants evaluation.

\section{QUICK LOOK}

\section{Current knowledge}

Hospital air quality indices include temperature and humidity levels, as well as the presence of particulate matter (PM), bacteria, fungi, and toxic metals. Air quality is often evaluated using carbon dioxide concentration, as this correlates with the number of people in a space and the PM concentrations.

\section{What this paper contributes to our knowledge}

Respiratory care center air quality is affected by use of open circuit suctioning. Bacteria and PM concentrations were highest in the summer and above indoor air quality standards. Health-care workers should wear appropriate personal protection during open suctioning.

To date, few studies have assessed air quality of RCCs, especially in mechanically ventilated patients with open suctioning. This study investigated the air quality of an RCC in a medical center over a 1-y period, and also assessed the possibility of health-care worker exposure to bioaerosols during open suctioning.

\section{Methods}

\section{Study Location}

This study was performed in a 24-bed RCC in Chang Gung Memorial Hospital in northern Taiwan, and the study protocol was approved by the institutional review board of Chang Gung Hospital. Indoor air quality was sampled weekly for $1 \mathrm{y}$. Air quality indices included temperature, relative humidity, concentrations of $\mathrm{CO}_{2}$, TVOCs, PM, bacteria, and fungi. The $\mathrm{PM}$ was classified into $\mathrm{PM}_{10}$ (aerodynamic diameter $\leq 10 \mu \mathrm{m}$ ), $\mathrm{PM}_{2.5}$ (aerodynamic diameter $\leq 2.5 \mu \mathrm{m}$ ), and $\mathrm{PM}_{1}$ (aerodynamic diameter $\leq 1 \mu \mathrm{m}$ ). To assess the influence of the open suctioning procedure, the PMs and bacterial concentrations were measured before, during, and after the procedures $(n=30)$.

The air change rate of the RCC in the hospital was $12 / \mathrm{h}$. Environmental surfaces of the RCC were disinfected with a solution containing $0.05 \%$ sodium hypochlorite for daily routine cleaning. Once environmental surfaces were contaminated with blood, body fluids, or secretions, a $0.5 \%$ sodium hypochlorite solution was used for disinfection.

\section{Indoor Air Sampling}

To better assess the risks associated with long-term exposure of health-care workers in the RCC, air quality in- 

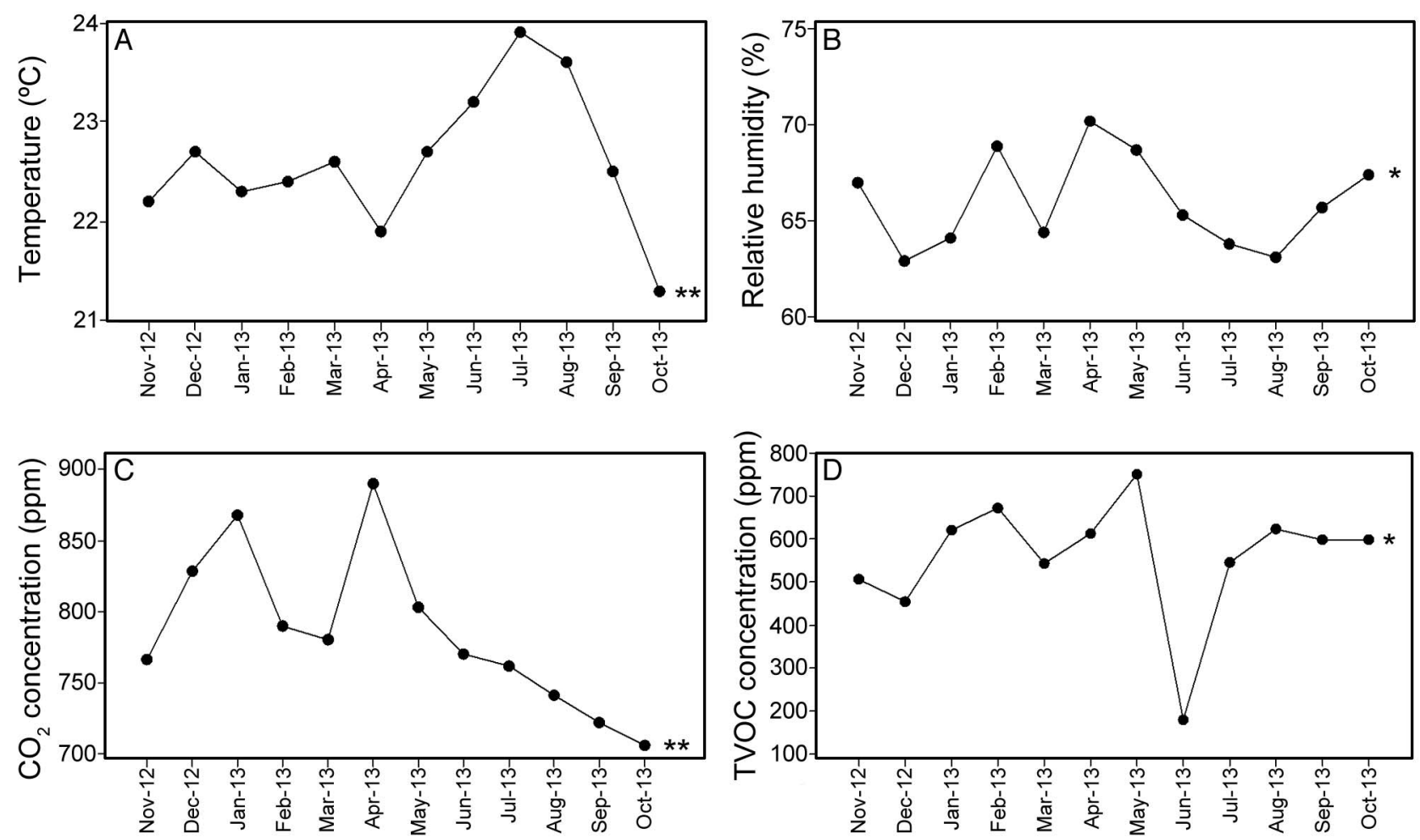

Fig. 1. Seasonal variation of temperature, relative humidity, and gaseous pollutant levels in the respiratory care center. ${ }^{\star} P<.05$, ${ }^{\star \star} P<.01$. TVOC $=$ total volatile organic compound.

dices were sampled over a long period. The temperature, relative humidity, and $\mathrm{CO}_{2}$ concentration in the $\mathrm{RCC}$ were measured using a digital psychrometer (TSI, Shoreview, Minnesota) at set intervals over an 8 -h period. Indoor TVOC concentrations were sampled using a ppbRAE monitor (model PGM-7600, RAE Systems, San Jose, California) over a consecutive 8-h period. The sampling head was attached to a water filter to prevent interference by moisture. The PM measurements were performed with a portable monitor (model 1.108 particle size analyzer, Rimm Aerosol Technik, Ainring, Germany) at 6-s intervals over a consecutive 8-h period. The measured particulate sizes ranged from 0.3 to $20 \mu \mathrm{m}$, and we divided PM into three sizes: $\mathrm{PM}_{10}, \mathrm{PM}_{2.5}$, and $\mathrm{PM}_{1}$.

Both bacterial and fungal concentrations were assessed using an Andersen one-stage viable impactor (N6; Thermo Fisher Scientific, Atlanta, Georgia), with $20 \mathrm{~mL}$ of tryptic soy agar (Difco/Becton Dickinson, Franklin Lakes, New Jersey) for bacterial sampling and malt extract agar for fungal sampling, with an air pump at $28.3 \mathrm{~L} / \mathrm{min}$ for $3 \mathrm{~min}$. The sampler comprises 400 orifices used to collect bacteria and fungi larger than $0.65 \mu \mathrm{m}$. All measurement instruments were positioned at $1.2-1.5 \mathrm{~m}$ above the floor, approximating the height of the human breathing zone. The plate samples were incubated at $30^{\circ} \mathrm{C}$ for $1-2 \mathrm{~d}$ for bacteria, and at $25^{\circ} \mathrm{C}$ for 3-4 $\mathrm{d}$ for fungi. Concentrations were reported as colony-forming units $(\mathrm{CFU}) / \mathrm{m}^{3}$, and were calculated using the positive-hole conversion table ${ }^{30}$ and the sampled air volume. The species of bacteria and fungi in the air were then identified. Identified bacterial genera included Bacillus, Micrococcus, Staphylococcus, Acinetobacter, Moraxella, Pseudomonas, and others. Additionally, fungal genera such as Aspergillus, Cladosporium, Penicillium, Scopulariopsis, Verticillium, and yeast were also identified.

\section{Air Sampling During Open Suctioning}

Bacterial and PM concentrations during open suctioning were measured at the following times: (1) 3-min sampling before the procedure to determine background air quality in the RCC, (2) 1.5-min sampling during the procedure, and (3) 3-min sampling 5 min after the procedure. Particulate concentrations were sampled using the continuous method, and bacterial contributions were sampled at the first and third samplings.

\section{Statistical Analysis}

Statistical analyses were performed using SPSS 21.0 (SPSS, Chicago, Illinois). Figures were constructed using GraphPad Prism 6.0 software (GraphPad Software, San 
Diego, California), and the significance level was set to 0.05. Seasonal variations in indices indicating particular concentrations in indoor air in the RCC and concentration variations in $\mathrm{PM} /$ bacteria concentrations during open suctioning were assessed using non-parametric repeated-measures analysis of variance for skewed distributed data. The correlation strength was assessed using the Spearman test for non-normally distributed data to determine the relationship between the airborne PM and bacteria concentrations during open suctioning.

\section{Results}

Air sampling was performed between November 2012 and October 2013. The 8-h averaged room temperature of the RCC was $22.6^{\circ} \mathrm{C}$, with a peak of $23.9^{\circ} \mathrm{C}$ in July and a low of $21.3^{\circ} \mathrm{C}$ in October (Fig. 1). Meanwhile, the mean relative humidity was $66 \%$, with a peak of $70.2 \%$ in April and a low of $62.9 \%$ in December. Additionally, the averaged $\mathrm{CO}_{2}$ concentration was $785.5 \mathrm{ppm}$, with a high of $889.9 \mathrm{ppm}$ in April and a low of $705.8 \mathrm{ppm}$ in October. The mean TVOC level was $558.6 \mathrm{ppb}$, with a peak of $750.73 \mathrm{ppb}$ in May and a low of $179.30 \mathrm{ppb}$ in June. The 24-h averaged PMs concentrations were $2.6 \mu \mathrm{g} / \mathrm{m}^{3}$ for the $\mathrm{PM}_{10}, 1.4 \mu \mathrm{g} / \mathrm{m}^{3}$ for $\mathrm{PM}_{2.5}$, and $1.1 \mu \mathrm{g} / \mathrm{m}^{3}$ for $\mathrm{PM}_{1}$. The PM levels $\left(\mathrm{PM}_{10}, \mathrm{PM}_{2.5}\right.$, and $\left.\mathrm{PM}_{1}\right)$ exhibited a peak in December and a low in May (Fig. 2). The indices showed a different monthly trend to the TVOCs at some times, yet always met Taiwan EPA standards. The average disqualification TVOC rate was $23.7 \%$, with a peak of $71.9 \%$ in August and a low of $0 \%$ in June.

The annual average bacterial concentration in RCC was 131.9 $\mathrm{CFU} / \mathrm{m}^{3}$. Meanwhile, the average morning concentration was $137.0 \mathrm{CFU} / \mathrm{m}^{3}$, with a high of $238.63 \mathrm{CFU} / \mathrm{m}^{3}$ in August and a low of $84.15 \mathrm{CFU} / \mathrm{m}^{3}$ in January. The average afternoon concentration was $126.9 \mathrm{CFU} / \mathrm{m}^{3}$, with a high of $237.21 \mathrm{CFU} / \mathrm{m}^{3}$ in November and a low of 38.89 $\mathrm{CFU} / \mathrm{m}^{3}$ in March. The concentrations changed significantly throughout the year, whether in the morning $(P=.02)$, afternoon $(P<.01)$, or whole day $(P<.01)$ (Fig. 3). The bacterial concentrations were compliant with the Taiwan EPA standards. The fungal concentration in RCC averaged $36.7 \mathrm{CFU} / \mathrm{m}^{3}$ over the whole year. Meanwhile, the highest and lowest airborne fungal concentrations in the morning and afternoon in the RCC occurred in May $\left(94.72 \mathrm{CFU} / \mathrm{m}^{3}\right)$ and October $\left(16.57 \mathrm{CFU} / \mathrm{m}^{3}\right)$, and in July $\left(122.37 \mathrm{CFU} / \mathrm{m}^{3}\right)$ and February $\left(7.92 \mathrm{CFU} / \mathrm{m}^{3}\right)$, respectively. This study thus found significant monthly variation in airborne fungal concentrations throughout the year.

The predominant bacterial genera in the air of the RCC included Micrococcus species, (80\%), Staphylococcus species (28\%), and coagulase-negative Staphylococcus (20\%) (Table 1). The highest morning bacterial concentrations were Micrococcus species $\left(53.61 \mathrm{CFU} / \mathrm{m}^{3}\right)$ and Coryne-
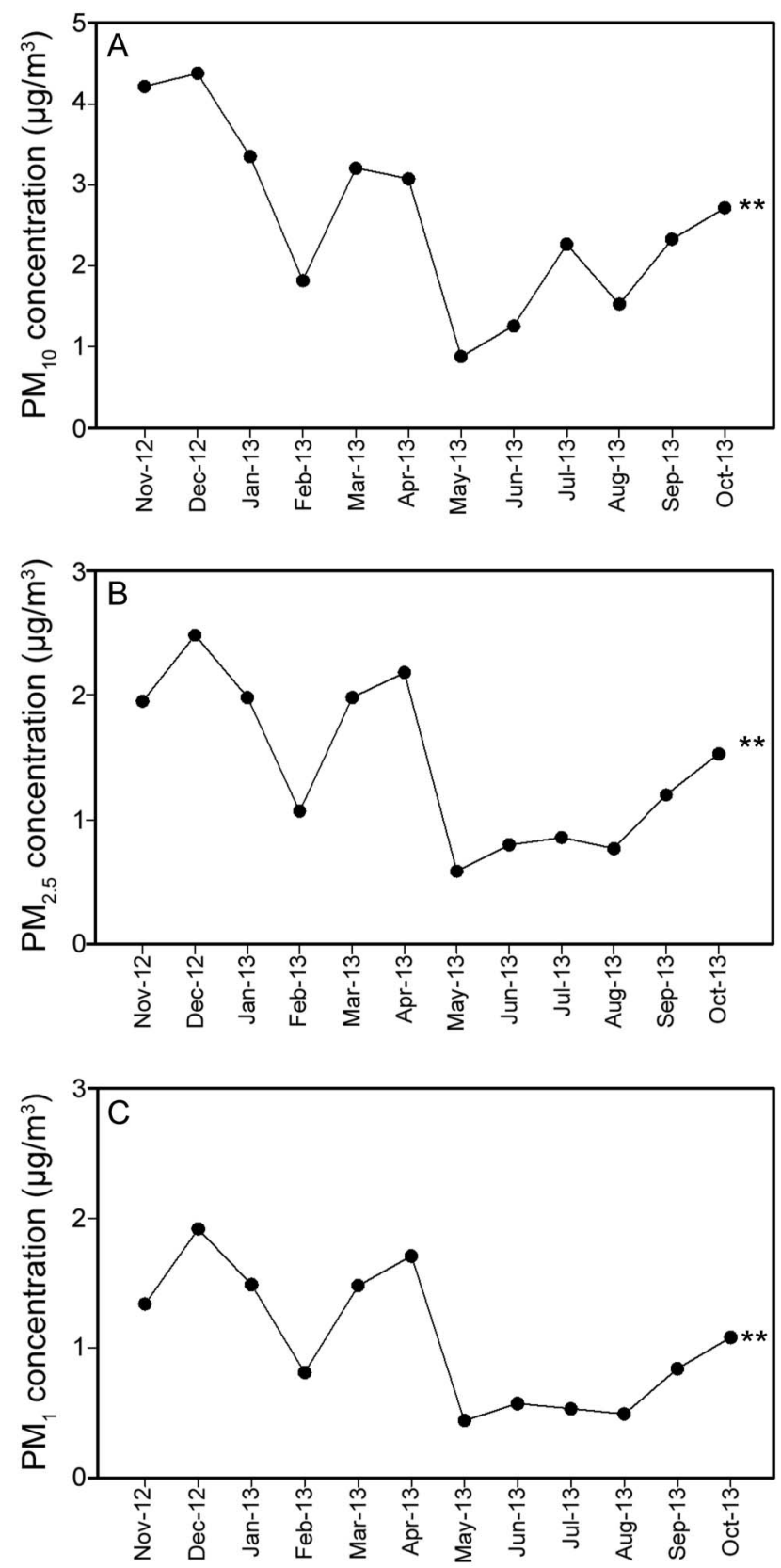

Fig. 2. Seasonal variation of $\mathrm{PM}_{10}, \mathrm{PM}_{2.5}$, and $\mathrm{PM}_{1}$ levels in the respiratory care center. ${ }^{* *} P<.01$.

bacterium species $\left(35.84 \mathrm{CFU} / \mathrm{m}^{3}\right)$, while, for the afternoon, they were Micrococcus species $\left(114.48 \mathrm{CFU} / \mathrm{m}^{3}\right)$ and Staphylococcus species $\left(35.86 \mathrm{CFU} / \mathrm{m}^{3}\right)$. The predominant fungal genera in the air of the RCC included Aspergillus species (60\%), Penicillium species (40\%), and Cladosporium species (16.67\%) (Table 2). The highest fungal concentrations in the morning were of yeast (47.77 $\mathrm{CFU} / \mathrm{m}^{3}$ ) and Aspergillus species $\left(29.98 \mathrm{CFU} / \mathrm{m}^{3}\right)$, while, in the afternoon, they were of Scopulariopsis species (36.06 $\left.\mathrm{CFU} / \mathrm{m}^{3}\right)$ and Trichoderma species $\left(24.10 \mathrm{CFU} / \mathrm{m}^{3}\right)$. 

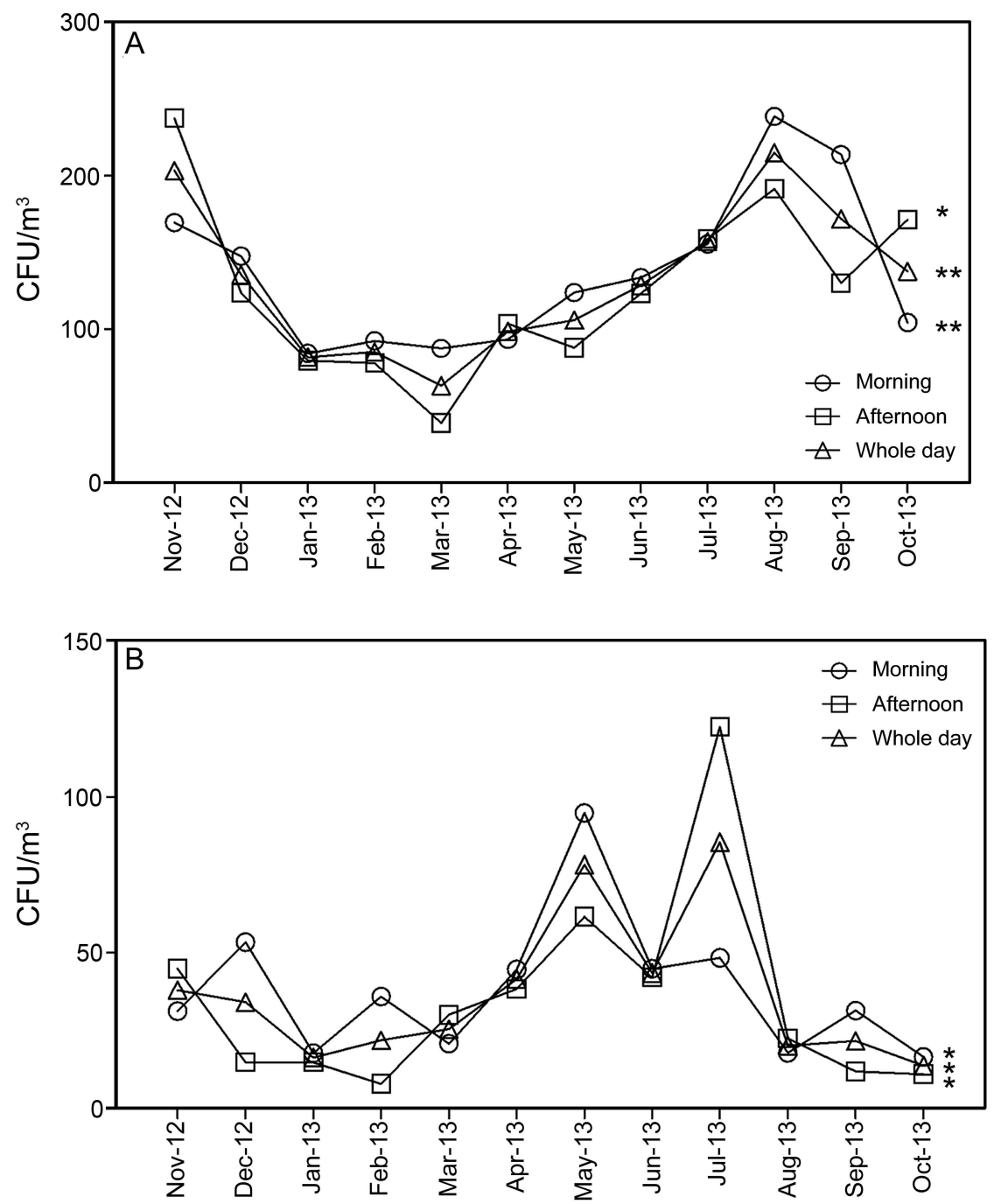

Fig. 3. Seasonal variation of $\mathrm{A}$ : bacterial and $\mathrm{B}$ : fungal concentrations in the respiratory care center. ${ }^{\star} P<.05$, ${ }^{\star \star} P<.01$.

Table 1. Isolation Rate and Concentration Distribution of Airborne Bacteria in the Respiratory Care Center of a Hospital

\begin{tabular}{|c|c|c|c|c|}
\hline \multirow{2}{*}{ Bacteria } & \multirow{2}{*}{ Isolation rate $(\%)^{*}$} & \multicolumn{3}{|c|}{ Concentration $\left(\mathrm{CFU} / \mathrm{m}^{3}\right) \dagger$} \\
\hline & & All & Morning & Afternoon \\
\hline Bacillus species & 12.00 & $23.75(11.78-23.98)$ & $23.75(11.78-23.98)$ & $0(0)$ \\
\hline Coagulase-negative Staphylococcus & 20.00 & $17.69(0-85.83)$ & $29.90(23.60-36.20)$ & $11.78(0-85.83)$ \\
\hline Corynebacterium species & 8.00 & $23.81(11.78-35.84)$ & $35.84(35.84-35.84)$ & $11.78(11.78-11.78)$ \\
\hline Flavimonas oryzihabitans & 4.00 & $11.78(11.78-11.78)$ & $0(0)$ & $11.78(11.78-11.78)$ \\
\hline Gardnerella vaginalis & 4.00 & $24.18(24.18-24.18)$ & $0(0)$ & $24.18(24.18-24.18)$ \\
\hline Micrococcus species & 80.00 & $78.51(23.56-279.15)$ & $53.61(23.56-266.20)$ & $114.48(23.81-279.15)$ \\
\hline Moraxella atlantae & 4.00 & $11.78(11.78-11.78)$ & $11.78(11.78-11.78)$ & $0(0)$ \\
\hline Staphylococcus species & 28.00 & $11.78(11.78-47.49)$ & $11.78(11.78-47.49)$ & $35.86(35.78-35.94)$ \\
\hline Stenotrophomonas (Xan) maltophilia & 4.00 & $11.78(11.78-11.78)$ & $11.78(11.78-11.78)$ & $0(0)$ \\
\hline Others & 52.00 & $24.18(11.78-71.68)$ & $35.55(11.79-71.68)$ & $24.18(11.78-59.90)$ \\
\hline
\end{tabular}


Air Quality in a Respiratory Care Center

Table 2. Isolation Rate and Concentration Distribution of Airborne Fungi in the Respiratory Care Center of a Hospital

\begin{tabular}{|c|c|c|c|c|}
\hline \multirow{2}{*}{ Fungi } & \multirow{2}{*}{ Isolation Rate $(\%)^{*}$} & \multicolumn{3}{|c|}{ Concentration $\left(\mathrm{CFU} / \mathrm{m}^{3}\right) \dagger$} \\
\hline & & All & Morning & Afternoon \\
\hline Acremonium species & 3.33 & $12.09(12.09-12.09)$ & $0(0)$ & $12.09(12.09-12.09)$ \\
\hline Aspergillus species & 60.00 & $12.04(11.87-59.63)$ & $29.98(11.87-59.63)$ & $11.99(11.87-24.18)$ \\
\hline Cladosporium species & 16.67 & $11.97(11.80-35.65)$ & $11.88(11.80-11.97)$ & $11.98(11.93-35.65)$ \\
\hline Fusarium species & 3.33 & $11.98(11.98-11.98)$ & $0(0)$ & $11.98(11.98-11.98)$ \\
\hline Paecelomyces species & 3.33 & $11.87(11.87-11.87)$ & $0(0)$ & $11.87(11.87-11.87)$ \\
\hline Penicillium species & 40.00 & $12.00(11.86-171.09)$ & $11.93(11.86-158.56)$ & $12.02(11.88-171.09)$ \\
\hline Scopulariopsis species & 10.00 & $35.97(12.01-36.15)$ & $12.01(12.01-12.01)$ & $36.06(35.97-36.15)$ \\
\hline Trichoderma species & 3.33 & $24.10(24.10-24.10)$ & $0(0)$ & $24.10(24.10-24.10)$ \\
\hline Verticillium species & 6.67 & $17.92(11.99-23.85)$ & $17.92(11.99-23.85)$ & $0(0)$ \\
\hline Yeast & 13.33 & $18.03(11.87-71.56)$ & $47.77(23.98-71.56)$ & $11.98(11.87-12.09)$ \\
\hline Others & 50.00 & $12.01(11.86-35.97)$ & $12.00(11.86-35.97)$ & $12.09(11.88-24.18)$ \\
\hline
\end{tabular}

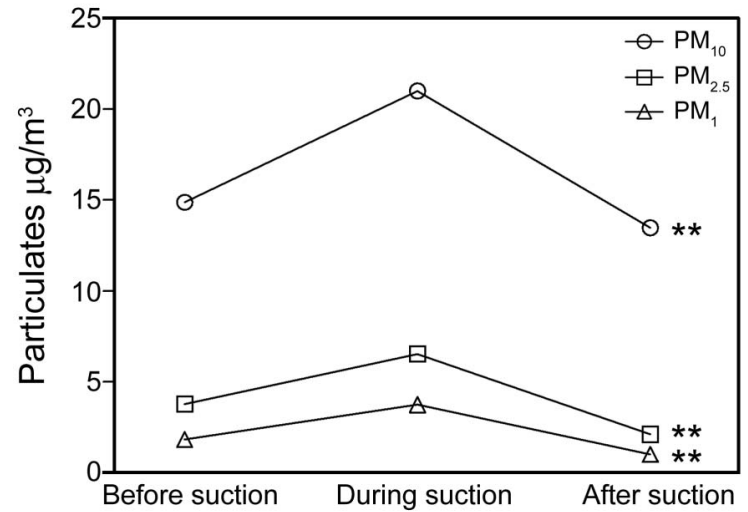

Fig. 4. Concentration variation of particulate matter (PM) during open suctioning procedure. ${ }^{\star \star} P<.01$ during suctioning vs after suctioning.

Furthermore, the geometric mean concentrations of PM were $14.88 \mu \mathrm{g} / \mathrm{m}^{3}$ for $\mathrm{PM}_{10}, 3.78 \mu \mathrm{g} / \mathrm{m}^{3}$ for $\mathrm{PM}_{2.5}$, and $1.84 \mu \mathrm{g} / \mathrm{m}^{3}$ for $\mathrm{PM}_{1}$ before open suctioning, versus $21.01 \mu \mathrm{g} / \mathrm{m}^{3}, 6.54 \mu \mathrm{g} / \mathrm{m}^{3}$, and $3.75 \mu \mathrm{g} / \mathrm{m}^{3}$ during the procedure, and $13.48 \mu \mathrm{g} / \mathrm{m}^{3}, 2.12 \mu \mathrm{g} / \mathrm{m}^{3}$, and $1.01 \mu \mathrm{g} / \mathrm{m}^{3}$ afterwards. The changes in PMs before, during, and after suctioning were significant $(P<.01)$ (Fig. 4). The geometric mean concentrations of $\mathrm{PM}_{10}$ and $\mathrm{PM}_{2.5}$ were significantly higher before suctioning than afterwards $(P<.1)$. The geometric mean PM concentrations during suctioning exceeded the averaged backgrounds in RCC $\left(\mathrm{PM}_{10}\right.$ for $2.6 \mu \mathrm{g} / \mathrm{m}^{3}, \mathrm{PM}_{2.5}$ for $1.4 \mu \mathrm{g} / \mathrm{m}^{3}$, and $\mathrm{PM}_{1}$ for $\left.1.1 \mu \mathrm{g} / \mathrm{m}^{3}\right)$.

To assess the influence of the open suctioning procedure, the air bacterial concentration $\left(290.45 \mathrm{CFU} / \mathrm{m}^{3}\right)$ during the procedure significantly exceeded that before $(191.52$ $\left.\mathrm{CFU} / \mathrm{m}^{3}, P=.02\right)$ and after $\left(187.46 \mathrm{CFU} / \mathrm{m}^{3}, P=.02\right)$

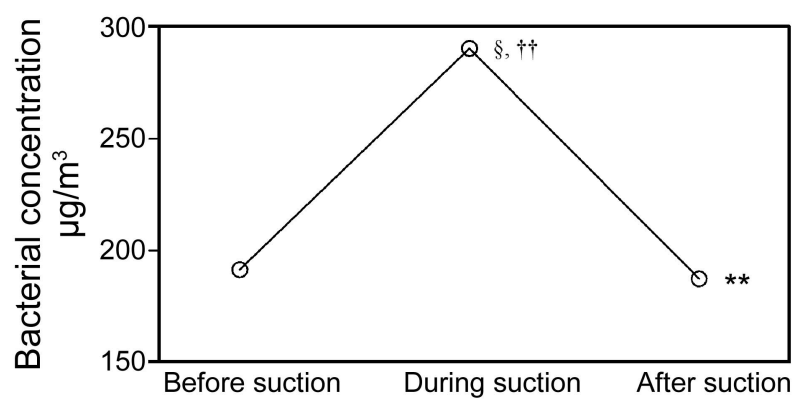

Fig. 5. Concentration variation of bacteria during open suctioning procedure. ${ }^{\star \star} P<.01$ during suction vs after suction; $\dagger+P<.05$ during suction vs after suction; $\S P<.05$ before suctioning vs during suctioning.

the procedure (Fig. 5). Airborne bacterial concentration exhibited significant change $(P<.01)$. Moreover, this study identified strong associations between airborne $\mathrm{PM}_{10}$ and $\mathrm{PM}_{2.5}$ levels $\left(\mathrm{r}_{\mathrm{s}}=0.824, P<.01\right)$, and between $\mathrm{PM}_{10}$ and $\mathrm{PM}_{1}\left(\mathrm{r}_{\mathrm{s}}=0.671, P<.01\right)$ during the start of suctioning around the heads of patients (Table 3). Additionally, bacterial concentration was strongly associated with $\mathrm{PM}_{10}$ $\left(\mathrm{r}_{\mathrm{s}}=0.380, P<.01\right), \mathrm{PM}_{2.5}\left(\mathrm{r}_{\mathrm{s}}=0.314, P<.01\right)$, and $\mathrm{PM}_{1}\left(\mathrm{r}_{\mathrm{s}}=0.228, P=.031\right)$.

\section{Discussion}

Most of the air quality indices measured in the RCC of a medical center in northern Taiwan met the indoor air quality standard of the Taiwan EPA, with the exception of TVOC levels. Possible reasons for TVOC levels sometimes failing to meet the standard may be related to alcohol evaporation from health-care worker hand hygiene prac- 
Table 3. Associations Between PM Level and Bacterial Concentration During Opening Suctioning in Mechanically Ventilated Patients

\begin{tabular}{lllll}
\hline \hline Concentration & $\mathrm{PM}_{10}$ & $\mathrm{PM}_{2.5}$ & $\mathrm{PM}_{1}$ & Bacteria \\
\hline $\mathrm{PM}_{10}$ & 1.000 & & & \\
$\mathrm{PM}_{2.5}$ & $0.824^{*}$ & 1.000 & & \\
$\mathrm{PM}_{1}$ & $0.671^{*}$ & $0.944^{*}$ & 1.000 & \\
Bacteria & $0.380^{*}$ & $0.314^{*}$ & $0.228 \dagger$ & 1.000 \\
& & & & \\
$* P<.01$. & & & & \\
$\dagger P<.05$. & & & & \\
$\mathrm{PM}=$ particulate matter & & & & \\
& & & & \\
\hline
\end{tabular}

tices following contact with patients, and the hypochlorite solution used for floor cleaning.

The microorganism distribution analyses conducted in this study demonstrated high concentrations of Micrococcus species, Corynebacterium species, and Staphylococcus species in the air of the RCC. Yeast, Aspergillus species, Scopulariopsis species, and Trichoderma species were the most common fungal genuses in the RCC. The results of this study differ from those of a previous study conducted in an ICU. ${ }^{19}$ However, the highest Staphylococcus species concentration occurred in the air of the RCC and the ICU. Both bacterial and fungal concentrations in the RCC peaked in the summer and fell in the winter, falling below 300 $\mathrm{CFU} / \mathrm{m}^{3}$. These concentrations were much lower than those obtained by a previous study on the air of the ICU. ${ }^{19}$ It was recommended to maintain 15 air changes/h in the ventilation of ICUs with highly infective and particularly vulnerable patients. ${ }^{31}$ Therefore, increasing air circulation and periodically maintaining the ventilation system are recommended to reduce the exposure of bioaerosol and TVOCs in hospitals.

Before performing open suctioning, the endotracheal tube must be disconnected from a ventilator circuit. A few phenomena are observable while the endotracheal tube of the patient is discontinued from a mechanical ventilator. First, the thoracic pressure of the patient becomes negative to the atmosphere, creating a risk of inhalation of airborne pathogens. Second, the mechanical ventilator provides a much higher flow to compensate for the low pressure in the ventilator circuit, and the condensates in the ventilator circuit may then be aerosolized from the forceful gas flow. This results in contamination of the air in the room. Finally, the opened ventilator circuit is frequently set on the chest of the patient, and the resuscitator for providing oxygen during suctioning is set on top of the bed sheet, an arrangement likely to cause contamination. Further contamination may then occur if proper hand hygiene is not carried out after contact with either the patient or hospital surfaces.
Significant changes occurred in PMs $\left(\mathrm{PM}_{10}, \mathrm{PM}_{2.5}, \mathrm{PM}_{1}\right)$ and bacterial levels during open suctioning on mechanically ventilated patients. The PM concentrations during open suctioning strongly exceeded those of the background air. This phenomenon demonstrated that the open suctioning procedure may increase the bioaerosol exposure risk for health-care workers in hospitals. Additionally, the analytical results also indicated that the concentrations of $\mathrm{PM}_{10}$ and $\mathrm{PM}_{2.5}$ during open suctioning exceeded those after open suctioning. This phenomenon can be attributed to the aerosolization of condensates and pathogens in the airway during open suctioning. Additionally, the $\mathrm{PM}_{10}$ concentration $\left(16.46 \mu \mathrm{g} / \mathrm{m}^{3}\right)$ measured near the patients was higher than the background concentration of the RCC $\left(2.6 \mathrm{CFU} / \mathrm{m}^{3}\right)$ in this study. Besides the open suctioning procedure, health-care worker activities such as walking around, turning patients, or chest physical therapy may also have caused elevated PM levels. The concentration of $\mathrm{PM}_{10}$ during open suctioning was clearly associated with the concentrations of $\mathrm{PM}_{2.5}$ and $\mathrm{PM}_{1}$, and all $3 \mathrm{PM}$ concentrations were significantly correlated with bacterial concentration. These outcomes resemble the results of previous studies. ${ }^{19}$

Additionally, the patients with tracheostomy tubes only require open suctioning. Thus, the risk of bioaerosol exposure of health-care workers during open suctioning in patients with tracheostomy tubes warrants further attention. Wearing suitable personal protective equipment is a good way to decrease the biological exposure of healthcare personnel in hospitals. However, the relationship between hospital air quality, infection rate of hospitalized patients, and occupationally acquired diseases is still not clear. Thus, it deserves further investigation. The limitation of this study was that only one medical center was selected. We will consider reproducing the data regarding evaluation of indoor air quality if more medical centers become available for study.

To ensure the occupational health and safety of healthcare workers, based on the results presented here, we suggest the following strategies: (1) periodically inspecting the ventilation system in the RCC, (2) increasing environmental disinfections in the summer, and (3) arranging continuing education on proper precautions and hand hygiene to minimize bioaerosol exposure risk in hospital healthcare workers.

\section{ACKNOWLEDGMENTS}

We thank Tsung-Ting Chi MSc and Yi-Chia Chen MSc of the Department of Respiratory Therapy, College of Medicine, Chang Gung University, for their assistance during this investigation. Mr Ted Knoy, freelance English editor/Hsinchu, is appreciated for his editorial assistance. 


\section{Air Quality in a Respiratory Care Center}

\section{REFERENCES}

1. American Society of Heating, Refrigerating, and Air-Conditioning Engineers (ASHRAE). ANSI/ASHRAE standard 62-2001: ventilation for acceptable indoor air quality. Atlanta, GA: American Society of Heating, Refrigerating, and Air-Conditioning Engineers; 2001.

2. Barbas CS, Couto LP. Do endotracheal tubes with suction above the cuff decrease the rate of ventilator-associated pneumonia, and are they cost-effective? Rev Bras Ter Intensiva 2012;24(4):320-321.

3. Gangneux JP, Bretagne S, Cordonnier C, Datry A, Derouin F, Grillot $\mathrm{R}$, et al. Prevention of nosocomial fungal infection: the French approach. Clin Infect Dis 2002;35(3):343-346.

4. Yocum JE, Cote WA, Benson FB. Effects of indoor air quality. In: Stern AE, ed. Air pollution VII. 3rd ed. New York, NY: Academic Press; 1977.

5. Nordström K, Norbäck D, Akselsson R. Effect of air humidification on the sick building syndrome and perceived indoor air quality in hospitals: a four month longitudinal study. Occup Environ Med 1994; 51(10):683-688

6. Buemi M, Floccari F, Nettò M, Allegra A, Grasso F, Mondio G, Perillo P. Environmental air pollution in an intensive care unit for nephrology and dialysis. J Nephrol 2000;13(6):433-436.

7. Slezakova K, Morais S, Pereira MD. Trace metals in size-fractionated particulate matter in a Portuguese hospital: exposure risks assessment and comparisons with other countries. Environ Sci Pollut Res 2014;21(5):3604-3620. doi:10.1007/s11356-013-2316-3.

8. Li CS, Hou PA. Bioaerosol characteristics in hospital clean rooms. Sci Total Environ 2003;305(1-3):169-176.

9. Wan GH, Lu SC, Tsai YH. Polymerase chain reaction used for the detection of airborne Mycobacterium tuberculosis in health care settings. Am J Infect Control 2004;32(1):17-22.

10. Afshari MA, Riazipour M, Kachuei R, Teimoori M, Einollahi B. A qualitative and quantitative study monitoring airborne fungal flora in the kidney transplant unit. Nephro Urol Mon 2013;5(2):736-740.

11. Mèheust D, Le Cann P, Gangneux JP. Rapid quantification of viable fungi in hospital environments: analysis of air and surface samples using solid-phase cytometry. J Hosp Infect 2012;83(2):122-126.

12. Tsai YH, Wan GH, Wu YK, Tsao KC. Airborne severe acute respiratory syndrome coronavirus concentrations in a negative-pressure isolation room. Infect Control Hosp Epidemiol 2006;27(5):523-525.

13. El-Sharkawy MF, Noweir ME. Indoor air quality levels in a university hospital in the Eastern Province of Saudi Arabia. J Family Community Med 2014;21(1):39-47. doi:10.4103/2230-8229.128778.

14. Scheff PA, Paulius VK, Huang SW, Conroy LM. Indoor air quality in a middle school, Part I: use of $\mathrm{CO}_{2}$ as a tracer for effective ventilation Appl Occup Environ Hyg 2000;15(11):824-834.

15. Li WM, Lee SC, Chan LY. Indoor air quality at nine shopping malls in Hong Kong. Sci Total Environ 2001;273(1-3):27-40.

16. Liu LJ, Krahmer M, Fox A, Feigley CE, Featherstone A, Saraf A, Larsson L. Investigation of the concentration of bacteria and their cell envelope components in indoor air in two elementary schools. J Air Waste Manag Assoc 2000;50(11):1957-1967.
17. Streifel AJ, Vesley D, Rhame FS, Murray B. Control of airborne fungal spores in a university hospital. Environ Int 1989;15(1-6):221227.

18. Perdelli F, Sartini M, Spagnolo AM, Dallera M, Lombardi R, Cristina ML. A problem of hospital hygiene: the presence of aspergilli in hospital wards with different air-conditioning features. Am J Infect Control 2006;34(5):264-268.

19. Tang CS, Chung FF, Lin MC, Wan GH. Impact of patient visiting activities on indoor climate in a medical intensive care unit: a 1-year longitudinal study. Am J Infect Control 2009;37(3):183-188.

20. Nardini S, Cagnin R, Invernizzi G, Ruprecht A, Boffi R, Formentini $\mathrm{S}$. Indoor particulate matter measurement as a tool in the process of the implementation of smoke-free hospitals. Monaldi Arch Chest Dis 2004;61(3):183-192.

21. Tang CS, Wan GH. Air quality monitoring of the post-operative recovery room and locations surrounding operating theaters in a medical center in Taiwan. PLoS One 2013;8(4):e61093.

22. Wan GH, Chung FF, Tang CS. Long-term surveillance of air quality in medical center operating rooms. Am J Infect Control 2011;39(4): 302-308.

23. Brown KW, Sarnat JA, Koutrakis P. Concentrations of $\mathrm{PM}_{2.5}$ mass and components in residential and non-residential indoor microenvironments: the sources and composition of particulate exposures study. J Expo Sci Environ Epidemiol 2012;22(2):161-172.

24. Hsu Y-C, Kung P-Y, Wu T-N, Shen Y-H. Characterization of indoor-air bioaerosols in Southern Taiwan. Aerosol Air Quality Res 2012;12(4):651-661. doi:10.4209/aaqr.2012.03.0070.

25. Sureda X, Fu M, López MJ, Martínez-Sánchez JM, Carabasa E, Saltó E, et al. Second-hand smoke in hospitals in Catalonia (2009): a cross-sectional study measuring $\mathrm{PM}_{2.5}$ and vapor-phase nicotine. Environ Res 2010;110(8):750-755. doi:10.1016/j.envres.2010.09.008.

26. Verma N, Taneja A. Particulate matter exposure in hospitals of urban city located in northern central India. Indian J Environ Prot 2011; 31(8):627-634

27. Wang Y-T, Chiu J-C, Hsu Y-C, Wu T-N, Shen Y-H, Wen S-B. Investigation on indoor air quality of public sites in Tainan area. Adv Mat Res 2011;255-260:1413-1417. doi:10.4028/www.scientific.net/ AMR.255-260.1413.

28. Yurtseven E, Erdogan MS, Ulus T, Sahin UA, Onat B, Erginoz E, et al. An assessment of indoor $\mathrm{PM}_{2.5}$ concentrations at a medical faculty in Istanbul, Turkey. Environ Protect Eng 2012;38(1):115-127.

29. Wang F, Bo L, Tang L, Lou J, Wu Y, Chen F, et al. Subglottic secretion drainage for preventing ventilator-associated pneumonia: an updated meta-analysis of randomized controlled trials. J Trauma Acute Care Surg 2012;72(5):1276-1285.

30. Andersen AA. New sampler for the collection, sizing and enumeration of viable airborne particles. J Bacteriol 1958;76(5):471-484.

31. Intensive Care Society. Standards for intensive care units. May, 1997. Available at http://www.ics.ac.uk/EasySiteWeb/GatewayLink.aspx ?alId=480. Accessed Apr 30, 2014.

This article is approved for Continuing Respiratory Care Education credit. For information and to obtain your CRCE

(free to AARC members) visit

www.rcjournal.com

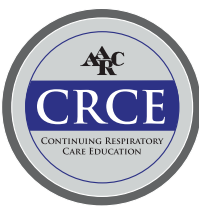

